\title{
Mesenchymal stem cells and their therapeutic applications in inflammatory bowel disease
}

\author{
Fei Mao ${ }^{1, *}$, Qiang Tu${ }^{2, *}$, Li Wang ${ }^{1}$, Fuliang $\mathrm{Chu}^{3}$, Xia $\mathrm{Li}^{4}$, Haiyan S. $\mathrm{Li}^{5}$ and Wenrong \\ $\mathbf{X} \mathbf{u}^{1}$ \\ ${ }^{1}$ Key Laboratory of Medical Science and Laboratory Medicine of Jiangsu Province, School of Medicine, Jiangsu University, \\ Zhenjiang, Jiangsu, P.R. China \\ 2 Jiangning Hospital of Nanjing, Nanjing, Jiangsu, P.R. China \\ ${ }^{3}$ Department of Lymphoma and Myeloma, The University of Texas MD Anderson Cancer Center, Houston, Texas, USA \\ ${ }^{4}$ Department of Gastroenterology, Binzhou Medical University Yantai Affiliated Hospital, Yantai, Shandong, P.R. China \\ ${ }^{5}$ Department of Immunology, The University of Texas MD Anderson Cancer Center, Houston, Texas, USA \\ * These authors have contributed equally to this work
}

Correspondence to: Wenrong XU, email: icls@ujs.edu.cn

Haiyan S. Li, email: haiyanli@mdanderson.org

Keywords: mesenchymal stem cell, inflammatory bowel disease, cell therapy, pericyte, tissue repair

Received: January 05, 2017

Accepted: March 06, 2017

Published: March 29, 2017

Copyright: Mao et al. This is an open-access article distributed under the terms of the Creative Commons Attribution License (CC-BY), which permits unrestricted use, distribution, and reproduction in any medium, provided the original author and source are credited.

ABSTRACT

Mesenchymal stem or stromal cells (MSCs) are non-hematopoietic stem cells that facilitate tissue regeneration through mechanisms involving selfrenewal and differentiation, supporting angiogenesis and tissue cell survival, and limiting inflammation. MSCs were originally identified and expanded in long-term cultures of cells from bone marrow and other organs; and their native identity was recently confined into pericytes and adventitial cells in vascularized tissue. The multipotency, as well as the trophic and immunosuppressive effects, of MSCs have prompted the rapid development of clinical applications for many diseases involving tissue inflammation and immune disorders, including inflammatory bowel disease. Although standard criteria have been established to define MSCs, their therapeutic efficacy has varied significantly among studies due to their natural heterogenicity. Thus, understanding the biological and immunological features of MSCs is critical to standardize and optimize MSCs-based therapy. In this review, we highlight the cellular and molecular mechanisms involved in MSCs-mediated tissue repair and immunosuppression. We also provide an update on the current development of MSCs-based clinical trials, with a detailed discussion of MSCbased cell therapy in inflammatory bowel disease.

\section{INTRODUCTION}

Mesenchymal stem or stromal cells (MSCs) represent a heterogeneous population of stromal cells that have self-renewal ability and multipotent differentiation potential. The presence of non-hematopoietic stem cells in the bone marrow was first proposed by Cohnheim about 150 years ago; who demonstrated the origination of wound-repairing cells from the distal bloodstream [1]. In 1968, Tavassoli and Crosby found that transplantation of intact bone marrow pieces into extramedullary sites in rodents could reconstitute both hematopoietic and adventitial structures [2], providing further evidence for the existence of non-hematopoietic stem cells.

The definitive discovery of MSCs has generally been credited to Friedenstein, who reported a plastic-adherent cell subpopulation from the bone marrow or spleen that retained colony-forming activities and could differentiate into osteoblasts in vitro and in vivo upon transplantation in the 1970s [3-5]. The term MSCs was not introduced until 
1991 by Arnold Caplan, who defined MSCs as stromal cells that are "capable of differentiating through a series of separate and unique lineage transitions into a variety of end-stage phenotypes" [6]. MSCs possess the abilities of self-renewal, tissue migration, and multipotency; they constitute tissue cells in the bone, cartilage, and fat. In addition, they can influence tissue repair via paracrine effects or direct cell-to-cell contact. Thus, the use of MSCs as potential cell therapy for a variety of diseases has been extensively explored, and the number of clinical trials of MSCs has risen nearly exponentially in recent years.

Inflammatory bowel disease (IBD), including ulcerative colitis (UC) and Crohn's disease (CD), is a chronic disease of the gastrointestinal tract that is characterized by perpetual idiopathic intestinal inflammation. IBD is more prevalent in western countries with an estimated rate of $0.5 \%$, and its prevalence is rapidly increasing in Asian countries. The etiology of IBD is unclear but involves a multifactorial interactions among genetic susceptibility, dysregulated immune responses, and environmental factors. Chronic inflammation in IBD is well known to predispose patients to colitis-associated cancer. Anti-inflammatory approaches, such as tumor necrosis factor (TNF) inhibitors, blocking antibodies against the interleukin (IL)-6 pathway, and Janus kinase inhibitors, have been actively evaluated to determine their efficacy in IBD treatment. With the rapid advances in MSC research, efforts have been made to investigate the therapeutic potential of MSCs in IBD. In this review, we discuss the mechanisms by which MSCs contribute to tissue repair and their applications in IBD treatment in experimental animals and patients.

\section{IDENTIFICATION, ORIGIN, AND DIVERSITY OF MSCS}

For many years since their discovery, MSCs have only been identified in cultures of developed organs based on their plastic adherence, phenotypic and functional characteristics. To standardize MSCs from different sources, the International Society of Cell Therapy specified three minimal criteria for MSCs in 2006: plastic adherence in culture, specific phenotypic markers $\left(\mathrm{CD} 105^{+} \mathrm{CD}^{+}\right.$

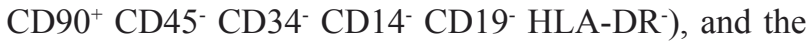
ability to differentiate into osteoblasts, adipocytes, and chondroblasts in vitro (Table 1). However, the extensive use of culture-based MSCs has raised some doubts about their native identity and anatomic distributions due to concerns on their phenotypic changes during in vitro expansion [7-11].

Multiple research groups have identified or isolated MSC-like cells from the vascular walls of distinct human organs [12-15], leading to the proposition that MSCs reside at perivascular sites. In 2008, Crisan et al. demonstrated that cultured $\mathrm{CD}_{146^{+}}$vascular pericytes (CD146+ ${ }^{+}$CD34- CD45- CD56-) from multiple human tissues exhibited features closely resembling those of culture-derived MSCs, providing the first evidence of tissue-resident MSCs. Other studies have reported that pericytes or perivascular precursors directly contribute to the development and regeneration of odontoblasts in dental pulp [16], skeletal muscle [17], and follicular dendritic cells [18], confirming their functional similarity to MSCs in situ. CD34+ adventitia cells (the outermost layer of blood vessels) were also found to express MSC markers and retain pluripotency [19-21]. Adventitia cells do not express typical pericyte markers such as CD146, $\alpha$ SMA, PDGFR $\beta$, and NG2; however, these markers could be upregulated in response to angiopoietin-2. These observations led to the hypothesis that MSCs are indeed adventitial cells and precursors of pericytes [19]. The identification of pericytes and adventitial cells as true MSCs has been confirmed by a sequential series of transplantation experiments, in which a single MSC generates a transplantable clonal progeny in recipients [21, 22] (Table 1). These results are consistent with previous findings that cells with MSC characteristics have been identified in virtually all vascularized tissue and organs, including bone marrow, adipose tissue, and liver, and can be culturally expanded ex vivo [23].

In addition, increasing evidence shows that pluripotent stem cells (PSs), including embryonic stem cells (ESCs) and induced pluripotent stem cells, can efficiently develop into cells with MSCs features via epithelial-to-mesenchymal transition (extensively reviewed in [24]) (Table 1). MSCs derived from vascularized tissue and PSs show no major differences in regard to their surface markers, differentiation potential, or immunotolerogenic ability [25-31]. However, PSderived MSCs inherit some features of their pluripotent progenitors, as they have faster proliferation rates than do tissue-derived MSCs, which make them more attractive for experimental and clinical use. Kimbrel et al. demonstrated that intraperitoneal delivery of PSs-derived MSCs significantly improved the survival of lupus-prone BWF1 mice and reduced the severity of experimentally induced uveitis [29]. Contemporaneously, another study using a mouse experimental autoimmune encephalomyelitis model showed that human ESCs-derived MSCs had better therapeutic performance in reducing symptoms and neuronal demyelination than bone marrow-derived MSCs [32].

With recent insights into the perivascular origin of MSCs and advances in flow cytometry techniques, MSCs can be freshly isolated from vascularized tissues to avoid traditional cell culture-based MSCs enrichment (Table 1). Adipose tissue is one of the most dispensable and easily accessible sources of perivascular MSCs; approximately $3-15 \times 10^{6} \mathrm{MSCs}$ can be isolated per 100 $\mathrm{ml}$ of lipoaspirate, which provides sufficient amounts for clinical applications [33, 34]. In addition, native MSCs can be directly purified from bone marrow, 


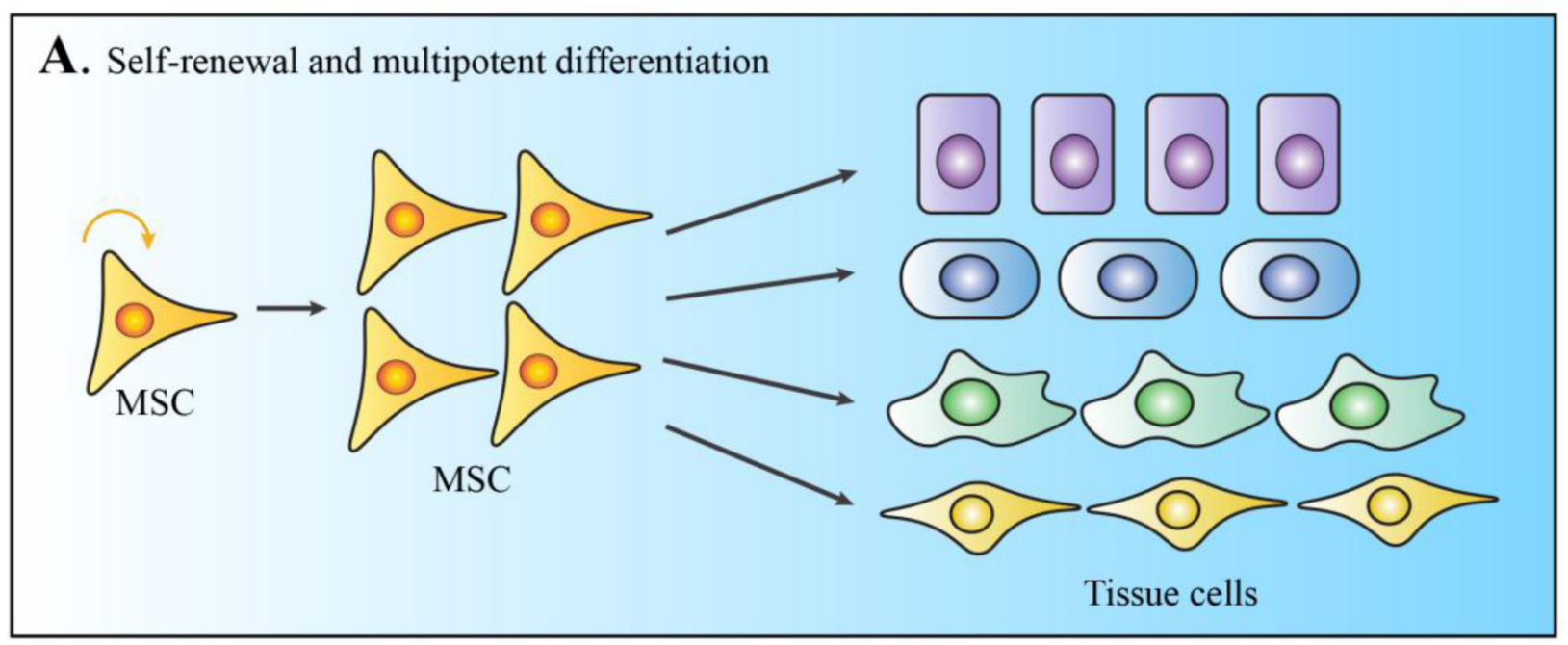

B. Tissue migration and repair

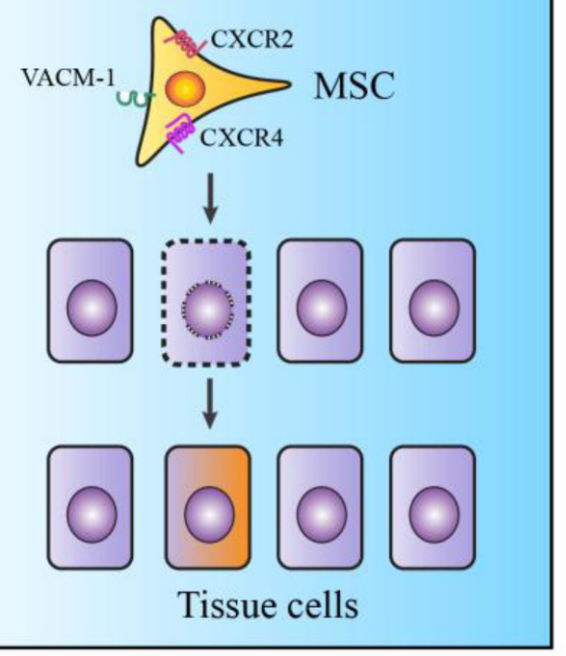

C. Cell contact-dependent mechanisms

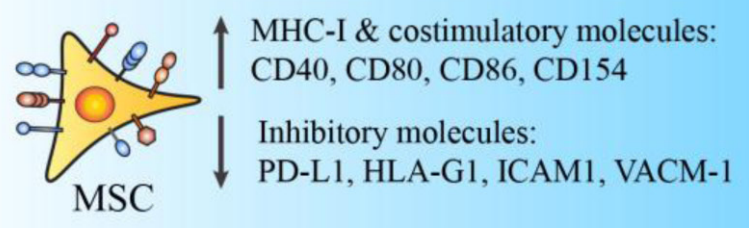

D. Secretion of soluble factors
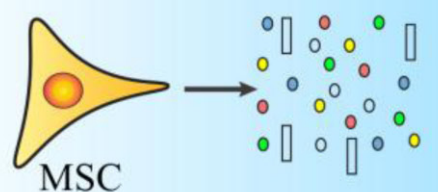

IDO, iNOS, PGE2, TGF- $\beta$, HGF, LIF, etc.

E. Transfer of molecules and/or organelles by EVs or TNTs
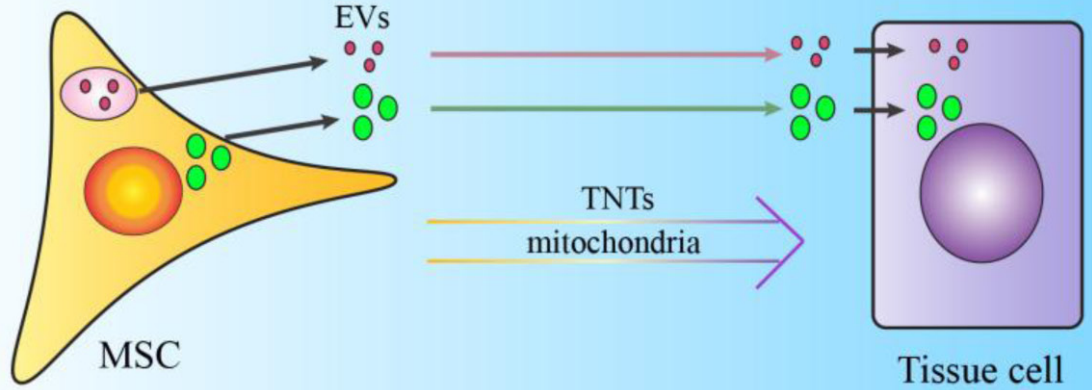

Tissue cell

Figure 1: Schematic demonstration of the diverse mechanisms involved in MSCs-mediated tissue repair. A. Selfrenewal and multipotent differentiation. B. Tissue migration and repair or replacement of damaged tissue cells. C. Cell contact-dependent immunosuppressive functions via surface molecules. D. Immunotolerance and angiogenesis mediated by secretion of soluble factors. E. Transfer of molecules or organelles by EVs or tunneling nanotubes (TNTs). All the demonstrated MSCs-mediated functions can be modulated by bioactive or inflammatory reagents, such as nitric oxide, IFN- $\gamma$, and TNF- $\alpha$. 
Table 1: Key characteristics of MSCs

\begin{tabular}{|c|c|}
\hline FEATURES & DESCIPTION \\
\hline Native precursor & Pericytes and adventitial cells \\
\hline Morphological characteristics & 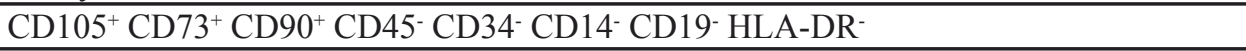 \\
\hline Phenotype & Plastic adherent \\
\hline Plasticity & Multipotent \\
\hline Differentiation potential & Osteoclasts, adipocytes, chondroblasts, etc. \\
\hline Tissue origin & Vascularized tissues (bone marrow, adipose tissue, umbilical cord), pluripotent stem cells \\
\hline Preparation methods & Long-term culture, sort-purification \\
\hline
\end{tabular}

umbilical cord, and other tissues but are often limited by low yield and unstable donor supply sites for clinical applications [35, 36]. MSCs from heterogeneous resources fulfill the common criteria of MSCs but differ in terms of immunophenotypes and biological potency, thus introducing variations and discrepancies in therapeutic efficacy among studies $[35,36]$. While traditional methods of MSC isolation rely on long-term culture, which is not only time-consuming but may also alter the phenotypic and functional properties of MSCs [7-11]; the purification of native MSCs is an alternative and neater cell source in regenerative therapy.

Of note, MSCs often represent a mixed population of cells with distinct phenotypic and biological properties. Increasing numbers of studies have used surface markers to further classify MSC subsets with respect to proliferation and survival rates, immunomodulatory features, and differentiation preference. A recent review by Mo et al. clearly addressed this issue [35]. External factors, such as isolation technique, culture conditions, cell source, and donor origin, can also influence the bioactivity and fate of MSCs in vivo [37]. Thus, understanding MSCs' heterogeneity and optimizing their isolation and expansion will significantly aid in the selection of MSCs for therapeutic advantages for different conditions.

\section{MECHANISMS INVOLVED IN MSCS- MEDIATED TISSUE REPAIR AND IMMUNOSUPPRESSION}

Tissue homing and tissue regeneration. Early studies by Friedenstein and many others clearly established that plastic-adherent MSCs are multipotent and readily develop into a variety of specialized tissue lineages ex vivo, such as osteoblasts, chondrocytes, adipocytes, and myoblasts [3-6, 38-42] (Figure 1A). With the optimization of techniques involved in the expansion and isolation of large quantities of MSCs in culture, studies have further characterized the behavior of these cells in vivo. MSCs are able to migrate and seed specifically into damaged tissue sites, where they can differentiate into functional cells to replace damaged or diseased cells [43-53] (Figure 1B). Trafficking-related molecules, such as CCR2, CXCR4, VCAM1, and MMP2, have been suggested to facilitate MSC homing [5459]. Upon their arrival at inflamed tissue, some MSCs developed into myofibroblasts in an experimental rat colitis model, with upregulated expression of $\alpha$-SMA and desmin [60]. Although MSCs are capable of replacing damaged tissue cells via self differentiation in situ, their tissue repair properties are largely due to their ability to stimulate the proliferation and survival of local tissue while inhibiting tissue cell apoptosis and fibrosis through the secretion of proteolytic enzymes and angiogenic factors [61-64]. Bioactive reagents, such as nitric oxide, IFN- $\gamma$, or TNF- $\alpha$, can also motivate MSCs' functions by altering their migration, differentiation, or immunologic properties, as detailed below [55, 65-67]. The degree and duration of MSCs' engraftment is a crucial factor affecting the efficacy of tissue repair and regeneration.

\section{Cell-intrinsic or cell contact-dependent immunotolerogenic properties}

MSCs lack the major MHC class II molecule and express only low levels of MHC class I and costimulatory molecules (CD40, CD80, CD86, and CD154) (Figure 1C). This unique feature of surface markers is generally considered as a hypoimmunogenic phenotype, which allows MSCs to evade immune recognition and clearance upon in vivo delivery. A recent review by Ankrum et al. argues against MSCs' immunoprivileged status, as several experimental and clinical studies have reported that allogeneic MSCs can elicit both innate and adaptive immune responses in recipient hosts [68]. Nevertheless, rejection of allogeneic MSCs occurs much more slowly than does rejection of other allogeneic cell types, such as fibroblasts [69]. The coinhibitory molecule PD-L1 has been found to be constitutively expressed, or to be induced by IFN- $\gamma$, on human and mouse MSCs derived from bone marrow, liver, and placenta [70-72] (Figure 1C). Using monoclonal antibodies or siRNAs, studies have revealed that increased amounts of surface PD-L1 are associated with MSC-mediated inhibitory effects on T cell proliferation and cytotoxicity in vitro.

HLA-G1 is another cell surface molecule with a similar inhibitory function, as the addition of HLAG1-blocking antibodies to MSC:T cell coculture nearly restored $\mathrm{T}$ cell proliferative responses to anti-CD3/ CD28 stimulation [73] (Figure 1C). Similar approaches 
have demonstrated that the adhesion molecules ICAM1 and VACM-1 are also involved in MSC-mediated immunotolerance, although to a lesser extent [74] (Figure 1C). In addition, bone marrow-derived MSCs express high levels of surface FasL, which directly induces $\mathrm{T}$ cell apoptosis and facilitates the production of $\mathrm{T}$ cellchemoattractive MCP-1 [75]. Of note, accumulating evidence indicates that the "reprogramming" of MSCs by proinflammatory cytokines derived from immune cells is necessary for their efficacy [67]. Thus, the balance between proinflammatory versus suppressive factors in the ex vivo culture and in vivo microenvironment greatly influences the function and duration of MSCs engraftment [68].

\section{Secretion of immunomodulatory mediators}

Besides their cell-intrinsic functions, MSCs are known to produce a wide spectrum of trophic factors that are critical in the suppression of immune responses and tissue regeneration (Figure 1D). By using neutralizing antibodies in a series of mixed lymphocyte reaction assays, Di Nicola et al. proposed that TGF $\beta 1$ and hepatocyte growth factor were the major soluble mediators responsible for the MSCs-mediated reduction in $\mathrm{T}$ cell proliferation [76]. Other research groups have suggested that the suppressive effects of MSCs largely depend on elevated prostaglandin E2 (PGE2) levels, as inhibitors of PGE2 efficiently abolished MSCs-mediated immunosuppression [77, 78]. Aggarwal and Pittenger demonstrated that MSC-derived PGE2 elicited a shift in T cell polarization from Th1 to Th2 subtype, while inducing dendritic cells to produce more IL-10 at the expense of reduced secretion of TNF- $\alpha$ and IL-12 [77]. Constitutive expression of TGF $\beta$, hepatocyte growth factor, and PGE2 in human MSCs was confirmed separately by Ryan et al [79].

The expression of the tryptophan-degrading enzyme, indoleamine-2, 3-dioxygenase (IDO), was also involved in the suppressive effects of MSCs in an IFN$\gamma$-dependent manner $[79,80]$. Similarly, IFN- $\gamma$ elicited the production of large quantities of inducible nitric oxidase synthase in MSCs, which is required for their immunosuppression [81]. Both inducible nitric oxidase synthase and IDO gene expression is dependent on IFN$\gamma$-mediated STAT1 activation, suggesting that STAT1 is critical for the immunosuppressive function of MSCs [51]. In addition, MSCs were reported to repress the activity of macrophages, dendritic cells, and T cells via TNF $\alpha$-stimulated gene protein 6 by activating the NF$\kappa \mathrm{B}$ signaling axis downstream of CD44 receptor [8284]. Stimulation of MSCs with TLR agonists poly I:C and LPS, IFN- $\gamma$, or TNF- $\alpha$ was reported to induce the expression of the above-mentioned factors [79, 82, 8587]. Other molecules, such as leukemia inhibitory factor, galectin, and insulin-like growth factor, are also believed to participate in the immunoregulatory network of MSCs [88-90].

\section{Transfer of bioactive materials by extracellular vesicles}

The term "extracellular vesicles (EVs)" generally refers to small phospholipid vesicles released by most, if not all, somatic cell types; they can be further classified as exosomes (30-100 nm), microvesicles (50-1000 $\mathrm{nm})$, and apoptotic bodies (1-5 $\mu \mathrm{m})$. Once released to the extracellular milieu, EVs can be picked up by other cells, leading to the intercellular exchange of bioactive components such as proteins, lipids, and nucleic acids. Exosomes are formed inside multi-vesicular bodies and released following fusion with the plasma membrane; they comprise a homogenous population. Microvesicles, on the other hand, are released by direct shedding from the plasma membrane and comprise more heterogeneous vesicles. Exosomes and microvesicles are better characterized EVs in MSCs and are referred to together as EVs in this review hereafter.

In 1997, Timmers et al. discovered that systemic delivery of MSCs-conditioned medium containing large compounds of 50-100 nm markedly reduced infarct size and improved cardiac performance in a porcine model of ischemia and reperfusion injury [91]. Three years later, the same group identified EVs as the active component in supernatants of human ESC-derived MSCs, which provided cardioprotection [92, 93]. MSC-derived EVs (MSC-EVs) have been investigated in different experimental settings and rodent models (Figure 1E). in vitro studies demonstrated that they exert their function directly on a wide range of immune cells involved in innate and adaptive immune responses, including monocytes, dendritic cells, B cells, and different $\mathrm{T}$ cell subsets (reviewed in [94]). In parallel, the results of numerous studies using animal models of organ injury indicate that MSC-EVs have great therapeutic benefits for injured hearts, livers, lungs, kidneys, brains, skin, and other organs and tissues by increasing tissue cell proliferation, reducing cell death, and limiting inflammation (reviewed in $[93,95]$ ). MSC-EVs are highly enriched in small RNA molecules, such as miRNA, which have been demonstrated to mediate their beneficial effects [96-100]. In addition, they deliver protein- and peptidebased paracrine effectors, such as cytokines, hormones, and transcription factors, which also participate in MSCmediated tissue repair [101-104]. In Burrello et al's review, mRNAs, transcription factors, and cytokines are the major effectors identified up date that play important roles in MSC-EV-mediated immunosuppression [104]. Future studies are required to fully elucidate the molecular content and mechanisms used by EVs to mediate their function. 
A

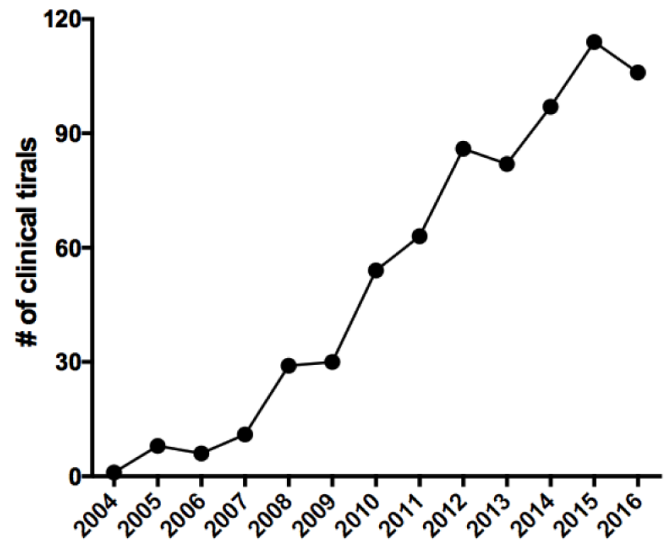

B

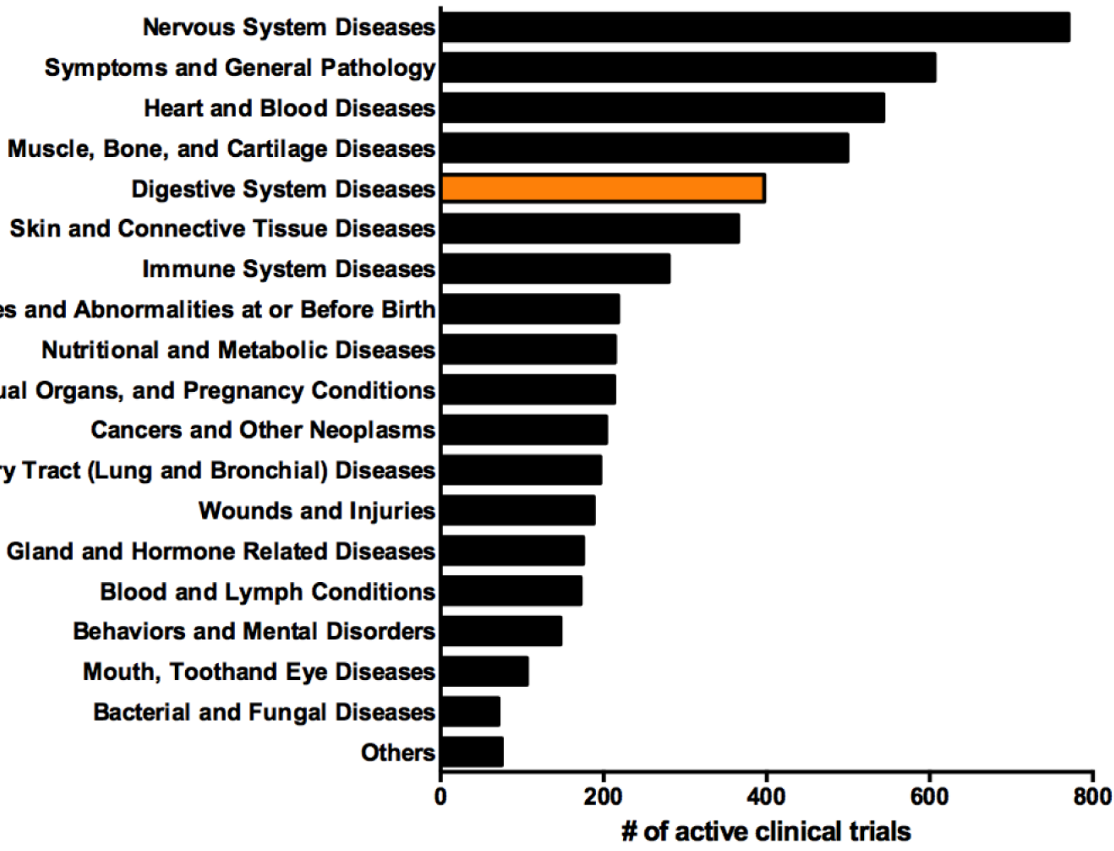

C

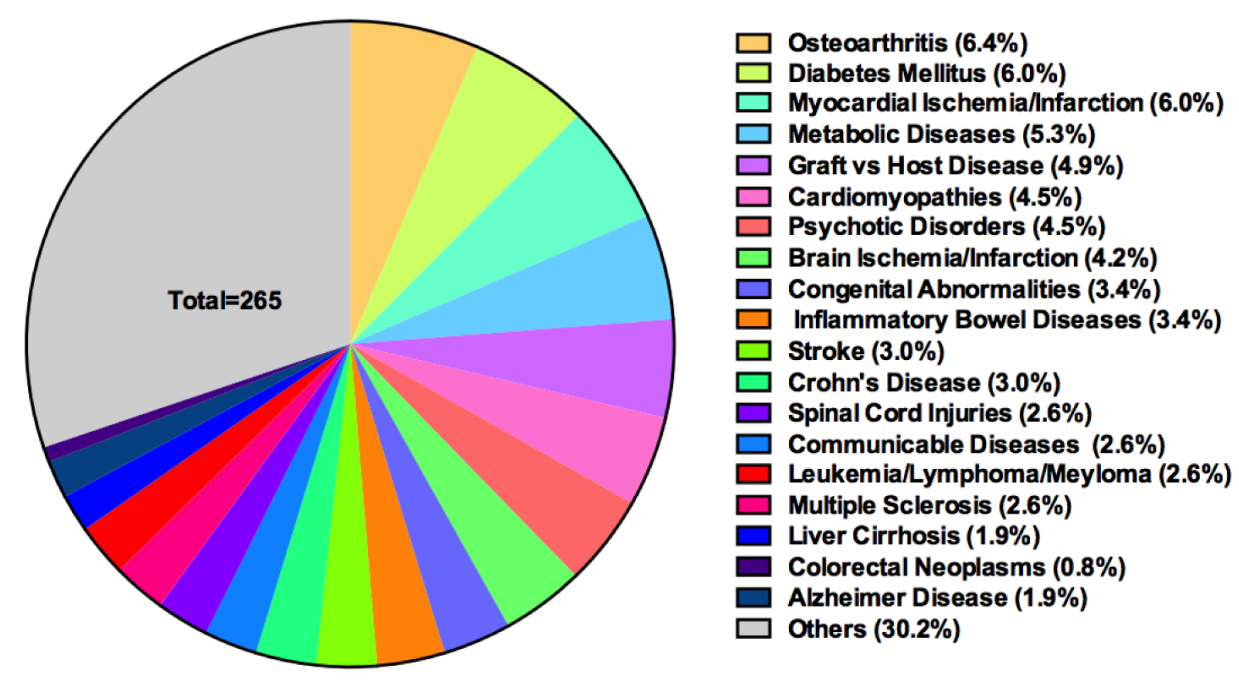

Figure 2: MSCs-based clinical trials on clinicaltrials.gov. A. Number of registered clinical trials of MSCs-based therapy from 2004 to 2016 (as of December 25, 2016). B. Distribution of ongoing MSCs-based therapy by disease category. C. Distribution of ongoing MSCs-based therapy by selected common diseases. 


\section{Transfer of mitochondria by tunneling nanotubes}

Mitochondria generate the majority of metabolic energy (ATP) in eukaryotic cells through respiration and oxidative phosphorylation. Intercellular transfer of mitochondria has been suggested to occur through tunneling nanotubes, which can rescue cells with impaired mitochondria function [105-107]. MSCs are proficient mitochondrial donors and express high levels of RHOT1, a key RhO GTPase that supports mitochondrial transport from MSCs to adaptor cells [108]. Mitochondrial transfer has been found between MSCs of different sources and a variety of damaged tissue cells ex vivo [109] (Figure 1E). Furthermore, recent studies have provided compelling evidence that mitochondrial transfer from administered MSCs to injured airway epithelial cells or vascular endothelial cells facilitates tissue regeneration and reduces organ function [107, 108, 110, 111]. One study further demonstrated that the capability of mitochondrial transfer among different MSCs was associated with their therapeutic effects in a cigarette smoke-induced model of lung injury [107]. Of note, mitochondrial dynamics and trafficking in MSCs are probably regulated by many signaling cascades beyond RHOT1 [106, 109]; thus, strategies that improve the mitochondrial transfer of MSCs may further improve MSC-based cell therapy.

\section{THERAPEUTIC APPLICATIONS OF MSCS IN IBD AND OTHER DISEASES}

Inflamed tissue damage and dysregulated immune response are the major pathogenic features of IBD, and MSCs use the molecular and cellular mechanisms discussed above in IBD treatment. An increase in effector $\mathrm{T}$ helper (Th) subset activation (Th1/Th17 in $\mathrm{CD}$ and Th2 in UC) has been documented, along with reduced regulatory $\mathrm{T}$ cell (Treg) levels in circulation in IBD patients [112-115]. These activated T cells are more resistant to apoptosis because of an imbalance of the anti- and pro-apoptotic Bcl-2 family proteins Bcl-2, Bcl$\mathrm{x}(\mathrm{L})$, and Bax [116-118]. Human or autologous MSCs, regardless of their origin and route of administration, have been demonstrated to engraft into inflamed intestinal and mesenteric lymph nodes in rodent models of colitis induced by dextran sodium sulfate or trinitrobenzene sulfonate, with documented tissue persistence time varying from 3 to 15 days [62, 119-121]. One study showed that a small proportion of transplanted MSCs was able to develop into colonic interstitial myofibroblasts [60]. Another study demonstrated that the systemic infusion of bone marrow MSCs promoted the differentiation and proliferation of intestinal epithelial cells, as evidenced by a remarkable increase in Ki67 and Lgr5 in damaged colonic tissue [62]. In these studies and some others, treatment with MSCs was able to suppress Th1/Th17 cells and boost Treg cells in mesenteric lymph nodes, accompanied by a systemic reduction in pro-inflammatory cytokines (IFN- $\gamma$, IL-17, IL-6, and TNF- $\alpha$ ) and an elevation of anti-inflammatory cytokine IL-10 [75, 119-122].

In addition, intravenous administration of bone marrow MSCs was reported to induce $\mathrm{T}$ cell apoptosis via FasL-Fas engagement in murine models of dextran sodium sulfate-induced colitis and fibrillin-1-mutated systemic sclerosis [75]. Phagocytosis of dead T cells by macrophages in turn triggered TGF- $\beta$ production, which led to enhanced Treg differentiation [75]. In the murine colitis model and other experimental settings, MSCs were shown to directly inhibit the antigen-presenting function of dendritic cells and macrophages, rendering them toward tolerogenic phenotype with increased IL-10 secretion and favored Treg induction [123-125]. More recently, in a trinitrobenzene sulfonate rat colitis model, the intravenous injection of MSC-EVs substantially reduced colonic damage and NF- $\mathrm{KB}$ activities, accompanied by decreased proinflammatory cytokines and increased IL10 [126]. Collectively, these findings indicate that MSCs exert stemness and immunosuppressive functions in animal models of colitis, which cooperatively suppress pathogenic $\mathrm{T}$ cells and reduce the disease phenotype.

The self-renewing, multipotency, and immunosuppressive potentials of MSCs have prompted increased clinical investigations of their use in the treatment of connective tissue diseases and immune disorders, including IBD, graft-versus-host disease, and autoimmune disease. We searched the clinicaltrials.gov database using the terms "mesenchymal stem cell" and "mesenchymal stromal cell" and retrieved a total of 687 clinical trials, with a nearly exponential increase since 2004 (Figure 2A). On the basis of disease categories used by clinicaltrials.gov, diseases of the nervous system, heart and blood; muscle, bone, and cartilage; skin and connective tissue; and immune system comprise more than $50 \%$ of ongoing clinical trials (total $=265$ ), with digestive tissue disease ranked fifth (Figure 2B). More specifically, IBD and colorectal neoplasms together are being studied in approximately $4.2 \%$ of ongoing clinical trials (Figure 2C). Although the niche function of bone marrow MSCs in supporting hematopoiesis has been recognized, the clinical applications of MSCs have been limited and only a few clinical trials have been conducted in hematopoietic cancers (Figure 2C).

In a phase I clinical study involving four patients with fistulising $\mathrm{CD}$, one intrafistular inoculation of autologous MSCs from adipose tissue culture $\left(3-30 \times 10^{6}\right)$ resulted in healing in 6 of 8 fistulas and reduced drainage in 2 of 8 fistulas at 8 weeks. The authors observed no adverse effects after 12-30 weeks' follow-up [127]. In the expanded phase II trial of 49 patients with complex cryptoglandular fistulas or $\mathrm{CD}$, the combination of fibrin glue and two doses of adipose-derived MSCs $\left(20 \times 10^{6}\right)$ resulted in significantly enhanced efficacy in comparison to the control group ( 17 of $24 v s 4$ of 25 for fistula healing, 
$\mathrm{RR}=4.43, p<0.001)$, with no MSC-related adverse effects [119]. Comparable results were obtained in studies from a separate group using similar MSCs generation protocols in patients with perianal fistulas associated with CD [128, 129]. Autologous MSCs derived from the bone marrow were only evaluated in 10 patients in a phase I clinical trial. The authors demonstrated that repeated intrafistular inoculation of MSCs greatly improved clinical remission ( 7 of 10 for complete closure and 3 of 10 for incomplete closure of fistula openings), accompanied by increased local and systemic Tregs [130].

Local administration of allogeneic MSCs in patients with refractory $\mathrm{CD}$ and complex fistulas achieved similar therapeutic benefits as autologous MSCs, although some adverse effects (i.e., anal abscess and uterine leiomyoma) were reported [131-133]. In these studies, MSCs were expanded from liposuctioned adipose tissue or bone marrow aspirates from healthy donors. Separately, Chinnadurai et al. reported that MSCs derived from CD patients were functionally similar to those of healthy controls in terms of $\mathrm{T}$ cell inhibition, and their immunosuppressive properties were dependent on IFN- $\gamma$ responsiveness and IDO [80]. In contrast, Zhu et al. demonstrated that although gastric cancer tissuederived MSC-like cells share many characteristics with bone marrow MSCs, they exhibit a stronger cancerpromoting capability, a phenotype that is dependent on miR155-5p-mediated NF-kB signaling [134]. More detailed comparisons between MSCs from different sources, especially those from inflamed or diseased tissues, are necessary for a better understanding of the microenvironment's influence on MSCs' characteristics.

The therapeutic effects of autologous MSCs on luminal IBDs via systemic administration are contradictory. One study showed improved clinical outcomes with adipose-derived MSCs [135]; two found that a large majority of patients experienced no clinical improvement or even worsening of the disease with bone marrow-derived MSCs [136, 137]. The inefficiency of MSC-based therapy on luminal IBDs could be because high percentages of MSCs were localized in the lungs after intravenous injection [138, 139]. Surprisingly, better results were obtained from trials using allogeneic MSCs expanded in cell culture of bone marrow or umbilical cord, where significant reduction in disease severity and clinical remission occurred in more than half the patients [140, 141]. While all the completed clinical trials with published results were performed with conventional tissue culturederived MSCs, recent advances in sort-purification from adipose tissues allow the enrichment of large quantities of native MSCs for clinical evaluation. Collectively, it is critical to assess the safety and efficacy of MSC therapy related to origin, dose, route of administration, and other modification strategies to further improve MSC-based clinical applications.

\section{CONCLUDING REMARKS}

The roles of MSCs as direct mesenchymal progenitors, anti-inflammatory modulators, and tissue niche cells not only present opportunities but also challenges to fully understanding the complexity of their physiological roles in situ. While the rapid translation of the results of biological studies of MSCs to therapy is important, more stringent criteria or a more strict definition of MSCs seems necessary to enforce standard clinical applications. As the function of MSCs is tightly influenced by the microenvironmental milieu, it is not surprising that MSC-based therapy does not always confer therapeutic benefits. Indeed, MSCs have been shown to exert protumorigenic effects in cancers, including colorectal cancer, by promoting cancer cell proliferation, formation of the tumor-associated stromal network, and angiogenesis [142, 143]. Thus, serious efforts are needed to further investigate and characterize the precise mechanisms involved in MSC-based tissue remodeling in a disease- and tissuespecific manner. In addition, optimized standards for MSCs isolation and expansion, delivery dose, and safety control are also required to establish intra-study or intracountry comparisons.

\section{ACKNOWLEDGMENTS}

This work was supported by grants from the National Natural Science Foundation of China (grant nos. 81670502, 81672416, and 81272481), the Jiangsu Key Research and Development Project (grant nos. BE2016717), the Jiangsu Province for Outstanding Sci-tech Innovation Team in Colleges and Universities (SJK2013-10), the China Postdoctoral Science Foundation (grant nos. 2015M571705, 2015M580403, and 2016T90431), Jiangsu Province's scientific and technological Supporting Program (grant no. BE2010703), the Scientific Research Foundation of Jiangsu University (grant no. FCJJ2015023), the opening project of the Key Laboratory of Embryo Molecular Biology, the Ministry of Health of China, the Shanghai Key Laboratory of Embryo and Reproduction Engineering (grant no. KF201601), the Priority Academic Program Development of Jiangsu Higher Education Institutions, NIH NIAID (grant no. RO1AI109294), and the MD Anderson Center for Inflammation and Cancer (to H.S.L.).

\section{CONFLICTS OF INTEREST}

No potential conflict of interest relevant to this article is reported.

\section{REFERENCES}

1. Cohnheim J. Ueber entzundung und eiterung. Path Anat 
Physiol Klin Med. 1867; 40:1-79.

2. Tavassoli M, Crosby WH. Transplantation of marrow to extramedullary sites. Science. 1968; 161:54-56.

3. Friedenstein AJ, Chailakhjan RK, Lalykina KS. The development of fibroblast colonies in monolayer cultures of guinea-pig bone marrow and spleen cells. Cell Tissue Kinet. 1970; 3:393-403.

4. Friedenstein AJ, Chailakhyan RK, Latsinik NV, Panasyuk AF, Keiliss-Borok IV. Stromal cells responsible for transferring the microenvironment of the hemopoietic tissues. Cloning in vitro and retransplantation in vivo. Transplantation. 1974; 17:331-40.

5. Friedenstein AJ, Gorskaja JF, Kulagina NN. Fibroblast precursors in normal and irradiated mouse hematopoietic organs. Exp Hematol. 1976; 4:267-74.

6. Caplan AI. Mesenchymal stem cells. J Orthop Res. 1991; 9:641-50.

7. Baxter MA, Wynn RF, Jowitt SN, Wraith JE, Fairbairn LJ, Bellantuono I. Study of telomere length reveals rapid aging of human marrow stromal cells following in vitro expansion. Stem Cells. 2004; 22:675-82.

8. Bonab MM, Alimoghaddam K, Talebian F, Ghaffari SH, Ghavamzadeh A, Nikbin B. Aging of mesenchymal stem cell in vitro. BMC Cell Biol. 2006; 7:14.

9. Dahl JA, Duggal S, Coulston N, Millar D, Melki J, Shahdadfar A, Brinchmann JE, Collas P. Genetic and epigenetic instability of human bone marrow mesenchymal stem cells expanded in autologous serum or fetal bovine serum. Int J Dev Biol. 2008; 52:1033-42.

10. Ren Z, Zhang YA, Chen Z. Spontaneous transformation of cynomolgus mesenchymal stem cells in vitro: further confirmation by short tandem repeat analysis. Exp Cell Res. 2012; 318:435-40.

11. Røsland GV, Svendsen A, Torsvik A, Sobala E, McCormack E, Immervoll H, Mysliwietz J, Tonn JC, Goldbrunner R, Lønning PE, Bjerkvig R, Schichor C. Longterm cultures of bone marrow-derived human mesenchymal stem cells frequently undergo spontaneous malignant transformation. Cancer Res. 2009; 69:5331-39.

12. Covas DT, Siufi JL, Silva AR, Orellana MD. Isolation and culture of umbilical vein mesenchymal stem cells. Braz J Med Biol Res. 2003; 36:1179-83.

13. Shi S, Gronthos S. Perivascular niche of postnatal mesenchymal stem cells in human bone marrow and dental pulp. J Bone Miner Res. 2003; 18:696-704.

14. Tintut Y, Alfonso Z, Saini T, Radcliff K, Watson K, Boström K, Demer LL. Multilineage potential of cells from the artery wall. Circulation. 2003; 108:2505-10.

15. Covas DT, Piccinato CE, Orellana MD, Siufi JL, Silva WA Jr, Proto-Siqueira R, Rizzatti EG, Neder L, Silva AR, Rocha $\mathrm{V}$, Zago MA. Mesenchymal stem cells can be obtained from the human saphena vein. Exp Cell Res. 2005; 309:340-44.

16. Feng J, Mantesso A, De Bari C, Nishiyama A, Sharpe PT. Dual origin of mesenchymal stem cells contributing to organ growth and repair. Proc Natl Acad Sci USA. 2011; 108:6503-08.

17. Dellavalle A, Maroli G, Covarello D, Azzoni E, Innocenzi A, Perani L, Antonini S, Sambasivan R, Brunelli S, Tajbakhsh S, Cossu G. Pericytes resident in postnatal skeletal muscle differentiate into muscle fibres and generate satellite cells. Nat Commun. 2011; 2:499.

18. Krautler NJ, Kana V, Kranich J, Tian Y, Perera D, Lemm D, Schwarz P, Armulik A, Browning JL, Tallquist M, Buch T, Oliveira-Martins JB, Zhu C, et al. Follicular dendritic cells emerge from ubiquitous perivascular precursors. Cell. 2012; 150:194-206.

19. Corselli M, Chen CW, Sun B, Yap S, Rubin JP, Péault B. The tunica adventitia of human arteries and veins as a source of mesenchymal stem cells. Stem Cells Dev. 2012; 21:1299-308.

20. Hoshino A, Chiba H, Nagai K, Ishii G, Ochiai A. Human vascular adventitial fibroblasts contain mesenchymal stem/ progenitor cells. Biochem Biophys Res Commun. 2008; 368:305-10.

21. Sacchetti B, Funari A, Michienzi S, Di Cesare S, Piersanti S, Saggio I, Tagliafico E, Ferrari S, Robey PG, Riminucci M, Bianco P. Self-renewing osteoprogenitors in bone marrow sinusoids can organize a hematopoietic microenvironment. Cell. 2007; 131:324-36.

22. Méndez-Ferrer S, Michurina TV, Ferraro F, Mazloom AR, Macarthur BD, Lira SA, Scadden DT, Ma'ayan A, Enikolopov GN, Frenette PS. Mesenchymal and haematopoietic stem cells form a unique bone marrow niche. Nature. 2010; 466:829-34.

23. Murray IR, Corselli M, Petrigliano FA, Soo C, Péault B. Recent insights into the identity of mesenchymal stem cells: implications for orthopaedic applications. Bone Joint J. 2014; 96-B:291-98.

24. Luzzani CD, Miriuka SG. Pluripotent Stem Cells as a Robust Source of Mesenchymal Stem Cells. Stem Cell Rev. 2017; 13:68-78.

25. Billing AM, Ben Hamidane H, Dib SS, Cotton RJ, Bhagwat AM, Kumar P, Hayat S, Yousri NA, Goswami N, Suhre K, Rafii A, Graumann J. Comprehensive transcriptomic and proteomic characterization of human mesenchymal stem cells reveals source specific cellular markers. Sci Rep. 2016; 6:21507.

26. Boyd NL, Robbins KR, Dhara SK, West FD, Stice SL. Human embryonic stem cell-derived mesoderm-like epithelium transitions to mesenchymal progenitor cells. Tissue Eng Part A. 2009; 15:1897-907.

27. de Peppo GM, Svensson S, Lennerås M, Synnergren J, Stenberg J, Strehl R, Hyllner J, Thomsen P, Karlsson C. Human embryonic mesodermal progenitors highly resemble human mesenchymal stem cells and display high potential for tissue engineering applications. Tissue Eng Part A. 2010; 16:2161-82.

28. Hematti P. Human embryonic stem cell-derived 
mesenchymal stromal cells. Transfusion. 2011; 51 Suppl 4:138S-144S.

29. Kimbrel EA, Kouris NA, Yavanian GJ, Chu J, Qin Y, Chan A, Singh RP, McCurdy D, Gordon L, Levinson RD, Lanza R. Mesenchymal stem cell population derived from human pluripotent stem cells displays potent immunomodulatory and therapeutic properties. Stem Cells Dev. 2014; 23:161124.

30. Sánchez L, Gutierrez-Aranda I, Ligero G, Rubio R, MuñozLópez M, García-Pérez JL, Ramos V, Real PJ, Bueno C, Rodríguez R, Delgado M, Menendez P. Enrichment of human ESC-derived multipotent mesenchymal stem cells with immunosuppressive and anti-inflammatory properties capable to protect against experimental inflammatory bowel disease. Stem Cells. 2011; 29:251-62.

31. Vodyanik MA, Yu J, Zhang X, Tian S, Stewart R, Thomson JA, Slukvin II. A mesoderm-derived precursor for mesenchymal stem and endothelial cells. Cell Stem Cell. 2010; 7:718-29.

32. Wang X, Kimbrel EA, Ijichi K, Paul D, Lazorchak AS, Chu J, Kouris NA, Yavanian GJ, Lu SJ, Pachter JS, Crocker SJ, Lanza R, Xu RH. Human ESC-derived MSCs outperform bone marrow MSCs in the treatment of an EAE model of multiple sclerosis. Stem Cell Reports. 2014; 3:115-30.

33. James AW, Zara JN, Corselli M, Askarinam A, Zhou AM, Hourfar A, Nguyen A, Megerdichian S, Asatrian G, Pang S, Stoker D, Zhang X, Wu B, et al. An abundant perivascular source of stem cells for bone tissue engineering. Stem Cells Transl Med. 2012; 1:673-84.

34. James AW, Zara JN, Zhang X, Askarinam A, Goyal R, Chiang M, Yuan W, Chang L, Corselli M, Shen J, Pang S, Stoker D, Wu B, et al. Perivascular stem cells: a prospectively purified mesenchymal stem cell population for bone tissue engineering. Stem Cells Transl Med. 2012; 1:510-19.

35. Mo M, Wang S, Zhou Y, Li H, Wu Y. Mesenchymal stem cell subpopulations: phenotype, property and therapeutic potential. Cell Mol Life Sci. 2016; 73:3311-21.

36. Murray IR, West CC, Hardy WR, James AW, Park TS, Nguyen A, Tawonsawatruk T, Lazzari L, Soo C, Péault B. Natural history of mesenchymal stem cells, from vessel walls to culture vessels. Cell Mol Life Sci. 2014; 71:135374.

37. Simovic Markovic B, Nikolic A, Gazdic M, Nurkovic J, Djordjevic I, Arsenijevic N, Stojkovic M, Lukic ML, Volarevic V. Pharmacological Inhibition of Gal-3 in Mesenchymal Stem Cells Enhances Their Capacity to Promote Alternative Activation of Macrophages in Dextran Sulphate Sodium-Induced Colitis. Stem Cells Int. 2016; 2016:2640746.

38. Howlett CR, Cavé J, Williamson M, Farmer J, Ali SY, Bab I, Owen ME. Mineralization in in vitro cultures of rabbit marrow stromal cells. Clin Orthop Relat Res. 1986251-63.

39. Keating A, Horsfall W, Hawley RG, Toneguzzo F. Effect of different promoters on expression of genes introduced into hematopoietic and marrow stromal cells by electroporation. Exp Hematol. 1990; 18:99-102.

40. Mardon HJ, Bee J, von der Mark K, Owen ME. Development of osteogenic tissue in diffusion chambers from early precursor cells in bone marrow of adult rats. Cell Tissue Res. 1987; 250:157-65.

41. Piersma AH, Brockbank KG, Ploemacher RE, van Vliet E, Brakel-van Peer KM, Visser PJ. Characterization of fibroblastic stromal cells from murine bone marrow. Exp Hematol. 1985; 13:237-43.

42. Piersma AH, Ploemacher RE, Brockbank KG. Transplantation of bone marrow fibroblastoid stromal cells in mice via the intravenous route. Br J Haematol. 1983; 54:285-90.

43. Dai W, Hale SL, Martin BJ, Kuang JQ, Dow JS, Wold LE, Kloner RA. Allogeneic mesenchymal stem cell transplantation in postinfarcted rat myocardium: short- and long-term effects. Circulation. 2005; 112:214-23.

44. Hofstetter CP, Schwarz EJ, Hess D, Widenfalk J, El Manira A, Prockop DJ, Olson L. Marrow stromal cells form guiding strands in the injured spinal cord and promote recovery. Proc Natl Acad Sci USA. 2002; 99:2199-204.

45. Horwitz EM, Gordon PL, Koo WK, Marx JC, Neel MD, McNall RY, Muul L, Hofmann T. Isolated allogeneic bone marrow-derived mesenchymal cells engraft and stimulate growth in children with osteogenesis imperfecta: implications for cell therapy of bone. Proc Natl Acad Sci USA. 2002; 99:8932-37.

46. Iso Y, Spees JL, Serrano C, Bakondi B, Pochampally R, Song YH, Sobel BE, Delafontaine P, Prockop DJ. Multipotent human stromal cells improve cardiac function after myocardial infarction in mice without long-term engraftment. Biochem Biophys Res Commun. 2007; 354:700-06.

47. Lee RH, Pulin AA, Seo MJ, Kota DJ, Ylostalo J, Larson BL, Semprun-Prieto L, Delafontaine P, Prockop DJ. Intravenous hMSCs improve myocardial infarction in mice because cells embolized in lung are activated to secrete the anti-inflammatory protein TSG-6. Cell Stem Cell. 2009; 5:54-63.

48. Lee RH, Seo MJ, Pulin AA, Gregory CA, Ylostalo J, Prockop DJ. The CD34-like protein PODXL and alpha6integrin (CD49f) identify early progenitor MSCs with increased clonogenicity and migration to infarcted heart in mice. Blood. 2009; 113:816-26.

49. Pittenger M, Vanguri P, Simonetti D, Young R. Adult mesenchymal stem cells: potential for muscle and tendon regeneration and use in gene therapy. J Musculoskelet Neuronal Interact. 2002; 2:309-20.

50. Mahmood A, Lu D, Lu M, Chopp M. Treatment of traumatic brain injury in adult rats with intravenous administration of human bone marrow stromal cells. Neurosurgery. 2003; 53:697-702; discussion 702-693. 
51. Chen J, Li Y, Wang L, Zhang Z, Lu D, Lu M, Chopp M. Therapeutic benefit of intravenous administration of bone marrow stromal cells after cerebral ischemia in rats. Stroke. 2001; 32:1005-11.

52. Rasulov MF, Vasilchenkov AV, Onishchenko NA, Krasheninnikov ME, Kravchenko VI, Gorshenin TL, Pidtsan RE, Potapov IV. First experience of the use bone marrow mesenchymal stem cells for the treatment of a patient with deep skin burns. Bull Exp Biol Med. 2005; 139:141-44.

53. Sakaida I, Terai S, Yamamoto N, Aoyama K, Ishikawa T, Nishina H, Okita K. Transplantation of bone marrow cells reduces CCl4-induced liver fibrosis in mice. Hepatology. 2004; 40:1304-11.

54. Belema-Bedada F, Uchida S, Martire A, Kostin S, Braun T. Efficient homing of multipotent adult mesenchymal stem cells depends on FROUNT-mediated clustering of CCR2. Cell Stem Cell. 2008; 2:566-75.

55. Cheng Z, Ou L, Zhou X, Li F, Jia X, Zhang Y, Liu X, Li Y, Ward CA, Melo LG, Kong D. Targeted migration of mesenchymal stem cells modified with CXCR4 gene to infarcted myocardium improves cardiac performance. Mol Ther. 2008; 16:571-79.

56. Ko IK, Kim BG, Awadallah A, Mikulan J, Lin P, Letterio JJ, Dennis JE. Targeting improves MSC treatment of inflammatory bowel disease. Mol Ther. 2010; 18:1365-72.

57. Ries C, Egea V, Karow M, Kolb H, Jochum M, Neth P. MMP-2, MT1-MMP, and TIMP-2 are essential for the invasive capacity of human mesenchymal stem cells: differential regulation by inflammatory cytokines. Blood. 2007; 109:4055-63.

58. Rüster B, Göttig S, Ludwig RJ, Bistrian R, Müller S, Seifried E, Gille J, Henschler R. Mesenchymal stem cells display coordinated rolling and adhesion behavior on endothelial cells. Blood. 2006; 108:3938-44.

59. Wynn RF, Hart CA, Corradi-Perini C, O’Neill L, Evans CA, Wraith JE, Fairbairn LJ, Bellantuono I. A small proportion of mesenchymal stem cells strongly expresses functionally active CXCR4 receptor capable of promoting migration to bone marrow. Blood. 2004; 104:2643-45.

60. Hayashi Y, Tsuji S, Tsujii M, Nishida T, Ishii S, Iijima H, Nakamura T, Eguchi H, Miyoshi E, Hayashi N, Kawano S. Topical implantation of mesenchymal stem cells has beneficial effects on healing of experimental colitis in rats. J Pharmacol Exp Ther. 2008; 326:523-31.

61. Caplan AI. Why are MSCs therapeutic? New data: new insight. J Pathol. 2009; 217:318-24.

62. Chen QQ, Yan L, Wang CZ, Wang WH, Shi H, Su BB, Zeng QH, Du HT, Wan J. Mesenchymal stem cells alleviate TNBS-induced colitis by modulating inflammatory and autoimmune responses. World J Gastroenterol. 2013; 19:4702-17.

63. Kachgal S, Putnam AJ. Mesenchymal stem cells from adipose and bone marrow promote angiogenesis via distinct cytokine and protease expression mechanisms. Angiogenesis. 2011; 14:47-59.

64. Prockop DJ. "Stemness" does not explain the repair of many tissues by mesenchymal stem/multipotent stromal cells (MSCs). Clin Pharmacol Ther. 2007; 82:241-43.

65. Fuseler JW, Valarmathi MT. Modulation of the migration and differentiation potential of adult bone marrow stromal stem cells by nitric oxide. Biomaterials. 2012; 33:1032-43.

66. Le Blanc K, Tammik C, Rosendahl K, Zetterberg E, Ringdén O. HLA expression and immunologic properties of differentiated and undifferentiated mesenchymal stem cells. Exp Hematol. 2003; 31:890-96.

67. Castro-Manrreza ME, Montesinos JJ. Immunoregulation by mesenchymal stem cells: biological aspects and clinical applications. J Immunol Res. 2015; 2015:394917.

68. Ankrum JA, Ong JF, Karp JM. Mesenchymal stem cells: immune evasive, not immune privileged. Nat Biotechnol. 2014; 32:252-60.

69. Zangi L, Margalit R, Reich-Zeliger S, Bachar-Lustig E, Beilhack A, Negrin R, Reisner Y. Direct imaging of immune rejection and memory induction by allogeneic mesenchymal stromal cells. Stem Cells. 2009; 27:2865-74.

70. de Mare-Bredemeijer EL, Mancham S, Verstegen MM, de Ruiter PE, van Gent R, O’Neill D, Tilanus HW, Metselaar HJ, de Jonge J, Kwekkeboom J, Hall SR, van der Laan LJ. Human graft-derived mesenchymal stromal cells potently suppress alloreactive T-cell responses. Stem Cells Dev. 2015; 24:1436-47.

71. Chang CJ, Yen ML, Chen YC, Chien CC, Huang HI, Bai $\mathrm{CH}$, Yen BL. Placenta-derived multipotent cells exhibit immunosuppressive properties that are enhanced in the presence of interferon-gamma. Stem Cells. 2006; 24:246677.

72. Sheng H, Wang $Y$, Jin $Y$, Zhang Q, Zhang Y, Wang L, Shen B, Yin S, Liu W, Cui L, Li N. A critical role of IFNgamma in priming MSC-mediated suppression of $\mathrm{T}$ cell proliferation through up-regulation of B7-H1. Cell Res. 2008; 18:846-57.

73. Giuliani M, Fleury M, Vernochet A, Ketroussi F, Clay D, Azzarone B, Lataillade JJ, Durrbach A. Long-lasting inhibitory effects of fetal liver mesenchymal stem cells on T-lymphocyte proliferation. PLoS One. 2011; 6:e19988.

74. Ren G, Zhao X, Zhang L, Zhang J, L'Huillier A, Ling W, Roberts AI, Le AD, Shi S, Shao C, Shi Y. Inflammatory cytokine-induced intercellular adhesion molecule-1 and vascular cell adhesion molecule-1 in mesenchymal stem cells are critical for immunosuppression. J Immunol. 2010; 184:2321-28.

75. Akiyama K, Chen C, Wang D, Xu X, Qu C, Yamaza T, Cai T, Chen W, Sun L, Shi S. Mesenchymal-stem-cell-induced immunoregulation involves FAS-ligand-/FAS-mediated T cell apoptosis. Cell Stem Cell. 2012; 10:544-55.

76. Di Nicola M, Carlo-Stella C, Magni M, Milanesi M, Longoni PD, Matteucci P, Grisanti S, Gianni AM. Human 
bone marrow stromal cells suppress T-lymphocyte proliferation induced by cellular or nonspecific mitogenic stimuli. Blood. 2002; 99:3838-43.

77. Aggarwal S, Pittenger MF. Human mesenchymal stem cells modulate allogeneic immune cell responses. Blood. 2005; 105:1815-22.

78. Najar M, Raicevic G, Boufker HI, Fayyad Kazan H, De Bruyn C, Meuleman N, Bron D, Toungouz M, Lagneaux L. Mesenchymal stromal cells use PGE2 to modulate activation and proliferation of lymphocyte subsets: combined comparison of adipose tissue, Wharton's Jelly and bone marrow sources. Cell Immunol. 2010; 264:17179.

79. Ryan JM, Barry F, Murphy JM, Mahon BP. Interferon-gamma does not break, but promotes the immunosuppressive capacity of adult human mesenchymal stem cells. Clin Exp Immunol. 2007; 149:353-63.

80. Chinnadurai R, Copland IB, Garcia MA, Petersen CT, Lewis CN, Waller EK, Kirk AD, Galipeau J. Cryopreserved Mesenchymal Stromal Cells Are Susceptible to T-Cell Mediated Apoptosis Which Is Partly Rescued by IFN $\gamma$ Licensing. Stem Cells. 2016; 34:2429-42.

81. Ren G, Zhang L, Zhao X, Xu G, Zhang Y, Roberts AI, Zhao RC, Shi Y. Mesenchymal stem cell-mediated immunosuppression occurs via concerted action of chemokines and nitric oxide. Cell Stem Cell. 2008; 2:14150.

82. Choi H, Lee RH, Bazhanov N, Oh JY, Prockop DJ. Anti-inflammatory protein TSG- 6 secreted by activated MSCs attenuates zymosan-induced mouse peritonitis by decreasing TLR2/NF- $\kappa \mathrm{B}$ signaling in resident macrophages. Blood. 2011; 118:330-38.

83. Kota DJ, Wiggins LL, Yoon N, Lee RH. TSG-6 produced by hMSCs delays the onset of autoimmune diabetes by suppressing Th1 development and enhancing tolerogenicity. Diabetes. 2013; 62:2048-58.

84. Oh JY, Lee RH, Yu JM, Ko JH, Lee HJ, Ko AY, Roddy GW, Prockop DJ. Intravenous mesenchymal stem cells prevented rejection of allogeneic corneal transplants by aborting the early inflammatory response. Mol Ther. 2012; 20:2143-52.

85. Waterman RS, Tomchuck SL, Henkle SL, Betancourt AM. A new mesenchymal stem cell (MSC) paradigm: polarization into a pro-inflammatory $\mathrm{MSC} 1$ or an Immunosuppressive MSC2 phenotype. PLoS One. 2010; 5:e10088.

86. Nemeth K, Mayer B, Mezey E. Modulation of bone marrow stromal cell functions in infectious diseases by toll-like receptor ligands. J Mol Med (Berl). 2010; 88:5-10.

87. Wetzler M, Talpaz M, Lowe DG, Baiocchi G, Gutterman JU, Kurzrock R. Constitutive expression of leukemia inhibitory factor RNA by human bone marrow stromal cells and modulation by IL-1, TNF-alpha, and TGF-beta. Exp Hematol. 1991; 19:347-51.
88. Majumdar MK, Thiede MA, Haynesworth SE, Bruder SP, Gerson SL. Human marrow-derived mesenchymal stem cells (MSCs) express hematopoietic cytokines and support long-term hematopoiesis when differentiated toward stromal and osteogenic lineages. J Hematother Stem Cell Res. 2000; 9:841-48.

89. Nasef A, Mazurier C, Bouchet S, François S, Chapel A, Thierry D, Gorin NC, Fouillard L. Leukemia inhibitory factor: role in human mesenchymal stem cells mediated immunosuppression. Cell Immunol. 2008; 253:16-22.

90. Najar M, Raicevic G, Crompot E, Fayyad-Kazan H, Bron D, Toungouz M, Lagneaux L. The Immunomodulatory Potential of Mesenchymal Stromal Cells: A Story of a Regulatory Network. J Immunother. 2016; 39:45-59.

91. Timmers L, Lim SK, Arslan F, Armstrong JS, Hoefer IE, Doevendans PA, Piek JJ, El Oakley RM, Choo A, Lee CN, Pasterkamp G, de Kleijn DP. Reduction of myocardial infarct size by human mesenchymal stem cell conditioned medium. Stem Cell Res (Amst). 2007; 1:129-37.

92. Lai RC, Arslan F, Lee MM, Sze NS, Choo A, Chen TS, Salto-Tellez M, Timmers L, Lee CN, El Oakley RM, Pasterkamp G, de Kleijn DP, Lim SK. Exosome secreted by MSC reduces myocardial ischemia/reperfusion injury. Stem Cell Res (Amst). 2010; 4:214-22.

93. Spees JL, Lee RH, Gregory CA. Mechanisms of mesenchymal stem/stromal cell function. Stem Cell Res Ther. 2016; 7:125.

94. Stephen J, Bravo EL, Colligan D, Fraser AR, Petrik J, Campbell JD. Mesenchymal stromal cells as multifunctional cellular therapeutics - a potential role for extracellular vesicles. Transfus Apheresis Sci. 2016; 55:62-69.

95. Marote A, Teixeira FG, Mendes-Pinheiro B, Salgado AJ. MSCs-Derived Exosomes: Cell-Secreted Nanovesicles with Regenerative Potential. Front Pharmacol. 2016; 7:231.

96. Feng Y, Huang W, Wani M, Yu X, Ashraf M. Ischemic preconditioning potentiates the protective effect of stem cells through secretion of exosomes by targeting Mecp2 via miR-22. PLoS One. 2014; 9:e88685.

97. Xin H, Li Y, Buller B, Katakowski M, Zhang Y, Wang X, Shang X, Zhang ZG, Chopp M. Exosome-mediated transfer of miR-133b from multipotent mesenchymal stromal cells to neural cells contributes to neurite outgrowth. Stem Cells. 2012; 30:1556-64.

98. Baglio SR, Rooijers K, Koppers-Lalic D, Verweij FJ, Pérez Lanzón M, Zini N, Naaijkens B, Perut F, Niessen HW, Baldini N, Pegtel DM. Human bone marrow- and adiposemesenchymal stem cells secrete exosomes enriched in distinctive miRNA and tRNA species. Stem Cell Res Ther. 2015; 6:127.

99. Lee HK, Finniss S, Cazacu S, Xiang C, Brodie C. Mesenchymal stem cells deliver exogenous miRNAs to neural cells and induce their differentiation and glutamate transporter expression. Stem Cells Dev. 2014; 23:2851-61.

100. Phinney DG, Di Giuseppe M, Njah J, Sala E, Shiva S, St 
Croix CM, Stolz DB, Watkins SC, Di YP, Leikauf GD, Kolls J, Riches DW, Deiuliis G, et al. Mesenchymal stem cells use extracellular vesicles to outsource mitophagy and shuttle microRNAs. Nat Commun. 2015; 6:8472.

101. Mokarizadeh A, Delirezh N, Morshedi A, Mosayebi G, Farshid AA, Mardani K. Microvesicles derived from mesenchymal stem cells: potent organelles for induction of tolerogenic signaling. Immunol Lett. 2012; 147:47-54.

102. Tomasoni S, Longaretti L, Rota C, Morigi M, Conti S, Gotti E, Capelli C, Introna M, Remuzzi G, Benigni A. Transfer of growth factor receptor mRNA via exosomes unravels the regenerative effect of mesenchymal stem cells. Stem Cells Dev. 2013; 22:772-80.

103. Zhang B, Wang M, Gong A, Zhang X, Wu X, Zhu Y, Shi H, Wu L, Zhu W, Qian H, Xu W. HucMSC-Exosome Mediated-Wnt4 Signaling Is Required for Cutaneous Wound Healing. Stem Cells. 2015; 33:2158-68.

104. Burrello J, Monticone S, Gai C, Gomez Y, Kholia S, Camussi G. Stem Cell-Derived Extracellular Vesicles and Immune-Modulation. Front Cell Dev Biol. 2016; 4:83.

105. Onfelt B, Nedvetzki S, Benninger RK, Purbhoo MA, Sowinski S, Hume AN, Seabra MC, Neil MA, French PM, Davis DM. Structurally distinct membrane nanotubes between human macrophages support long-distance vesicular traffic or surfing of bacteria. J Immunol. 2006; 177:8476-83.

106. Spees JL, Olson SD, Whitney MJ, Prockop DJ. Mitochondrial transfer between cells can rescue aerobic respiration. Proc Natl Acad Sci USA. 2006; 103:1283-88.

107. Li X, Zhang Y, Yeung SC, Liang Y, Liang X, Ding Y, Ip MS, Tse HF, Mak JC, Lian Q. Mitochondrial transfer of induced pluripotent stem cell-derived mesenchymal stem cells to airway epithelial cells attenuates cigarette smokeinduced damage. Am J Respir Cell Mol Biol. 2014; 51:45565.

108. Ahmad T, Mukherjee S, Pattnaik B, Kumar M, Singh S, Kumar M, Rehman R, Tiwari BK, Jha KA, Barhanpurkar AP, Wani MR, Roy SS, Mabalirajan U, et al. Miro1 regulates intercellular mitochondrial transport \& enhances mesenchymal stem cell rescue efficacy. EMBO J. 2014; 33:994-1010.

109. Hsu YC, Wu YT, Yu TH, Wei YH. Mitochondria in mesenchymal stem cell biology and cell therapy: from cellular differentiation to mitochondrial transfer. Semin Cell Dev Biol. 2016; 52:119-31.

110. Islam MN, Das SR, Emin MT, Wei M, Sun L, Westphalen K, Rowlands DJ, Quadri SK, Bhattacharya S, Bhattacharya J. Mitochondrial transfer from bone-marrow-derived stromal cells to pulmonary alveoli protects against acute lung injury. Nat Med. 2012; 18:759-65.

111. Liu K, Ji K, Guo L, Wu W, Lu H, Shan P, Yan C. Mesenchymal stem cells rescue injured endothelial cells in an in vitro ischemia-reperfusion model via tunneling nanotube like structure-mediated mitochondrial transfer.
Microvasc Res. 2014; 92:10-18.

112. Bandzar S, Gupta S, Platt MO. Crohn's disease: a review of treatment options and current research. Cell Immunol. 2013; 286:45-52.

113. Chao K, Zhang S, Yao J, He Y, Chen B, Zeng Z, Zhong B, Chen M. Imbalances of CD4(+) T-cell subgroups in Crohn's disease and their relationship with disease activity and prognosis. J Gastroenterol Hepatol. 2014; 29:1808-14.

114. Sisakhtnezhad S, Alimoradi E, Akrami H. External factors influencing mesenchymal stem cell fate in vitro. Eur J Cell Biol. 2017; 96:13-33.

115. Strober W, Fuss IJ. Proinflammatory cytokines in the pathogenesis of inflammatory bowel diseases. Gastroenterology. 2011; 140:1756-67.

116. Ina K, Itoh J, Fukushima K, Kusugami K, Yamaguchi T, Kyokane K, Imada A, Binion DG, Musso A, West GA, Dobrea GM, McCormick TS, Lapetina EG, et al. Resistance of Crohn's disease T cells to multiple apoptotic signals is associated with a Bcl-2/Bax mucosal imbalance. J Immunol. 1999; 163:1081-90.

117. Itoh J, de La Motte C, Strong SA, Levine AD, Fiocchi C. Decreased Bax expression by mucosal T cells favours resistance to apoptosis in Crohn's disease. Gut. 2001; 49:35-41.

118. Dias CB, Milanski M, Portovedo M, Horita V, Ayrizono ML, Planell N, Coy CS, Velloso LA, Meirelles LR, Leal RF. Defective apoptosis in intestinal and mesenteric adipose tissue of Crohn's disease patients. PLoS One. 2014; 9:e98547.

119. González MA, Gonzalez-Rey E, Rico L, Büscher D, Delgado M. Adipose-derived mesenchymal stem cells alleviate experimental colitis by inhibiting inflammatory and autoimmune responses. Gastroenterology. 2009; 136:978-89.

120. He XW, He XS, Lian L, Wu XJ, Lan P. Systemic infusion of bone marrow-derived mesenchymal stem cells for treatment of experimental colitis in mice. Dig Dis Sci. 2012; 57:3136-44.

121. Liang L, Dong C, Chen X, Fang Z, Xu J, Liu M, Zhang X, Gu DS, Wang D, Du W, Zhu D, Han ZC. Human umbilical cord mesenchymal stem cells ameliorate mice trinitrobenzene sulfonic acid (TNBS)-induced colitis. Cell Transplant. 2011; 20:1395-408.

122. Gonzalez-Rey E, Anderson P, González MA, Rico L, Büscher D, Delgado M. Human adult stem cells derived from adipose tissue protect against experimental colitis and sepsis. Gut. 2009; 58:929-39.

123. Anderson P, Souza-Moreira L, Morell M, Caro M, O'Valle F, Gonzalez-Rey E, Delgado M. Adipose-derived mesenchymal stromal cells induce immunomodulatory macrophages which protect from experimental colitis and sepsis. Gut. 2013; 62:1131-41.

124. Chiesa S, Morbelli S, Morando S, Massollo M, Marini C, Bertoni A, Frassoni F, Bartolomé ST, Sambuceti G, 
Traggiai E, Uccelli A. Mesenchymal stem cells impair in vivo T-cell priming by dendritic cells. Proc Natl Acad Sci USA. 2011; 108:17384-89.

125. Parekkadan B, Upadhyay R, Dunham J, Iwamoto Y, Mizoguchi E, Mizoguchi A, Weissleder R, Yarmush ML. Bone marrow stromal cell transplants prevent experimental enterocolitis and require host $\mathrm{CD} 11 \mathrm{~b}+$ splenocytes. Gastroenterology. 2011; 140:966-75.

126. Yang J, Liu XX, Fan H, Tang Q, Shou ZX, Zuo DM, Zou Z, Xu M, Chen QY, Peng Y, Deng SJ, Liu YJ. Extracellular Vesicles Derived from Bone Marrow Mesenchymal Stem Cells Protect against Experimental Colitis via Attenuating Colon Inflammation, Oxidative Stress and Apoptosis. PLoS One. 2015; 10:e140551.

127. García-Olmo D, García-Arranz M, Herreros D, Pascual I, Peiro C, Rodríguez-Montes JA. A phase I clinical trial of the treatment of Crohn's fistula by adipose mesenchymal stem cell transplantation. Dis Colon Rectum. 2005; 48:1416-23.

128. Cho YB, Lee WY, Park KJ, Kim M, Yoo HW, Yu CS. Autologous adipose tissue-derived stem cells for the treatment of Crohn's fistula: a phase I clinical study. Cell Transplant. 2013; 22:279-85.

129. Lee WY, Park KJ, Cho YB, Yoon SN, Song KH, Kim DS, Jung SH, Kim M, Yoo HW, Kim I, Ha H, Yu CS. Autologous adipose tissue-derived stem cells treatment demonstrated favorable and sustainable therapeutic effect for Crohn's fistula. Stem Cells. 2013; 31:2575-81.

130. Ciccocioppo R, Bernardo ME, Sgarella A, Maccario R, Avanzini MA, Ubezio C, Minelli A, Alvisi C, Vanoli A, Calliada F, Dionigi P, Perotti C, Locatelli F, Corazza GR. Autologous bone marrow-derived mesenchymal stromal cells in the treatment of fistulising Crohn's disease. Gut. 2011; 60:788-98.

131. de la Portilla F, Alba F, García-Olmo D, Herrerías JM, González FX, Galindo A. Expanded allogeneic adiposederived stem cells (eASCs) for the treatment of complex perianal fistula in Crohn's disease: results from a multicenter phase I/IIa clinical trial. Int J Colorectal Dis. 2013; 28:313-23.

132. Molendijk I, Bonsing BA, Roelofs H, Peeters KC, Wasser MN, Dijkstra G, van der Woude CJ, Duijvestein M, Veenendaal RA, Zwaginga JJ, Verspaget HW, Fibbe WE, van der Meulen-de, et al. Allogeneic Bone MarrowDerived Mesenchymal Stromal Cells Promote Healing of Refractory Perianal Fistulas in Patients With Crohn's Disease. Gastroenterology. 2015; 149:918-927 e916.

133. Panés J, García-Olmo D, Van Assche G, Colombel JF, Reinisch W, Baumgart DC, Dignass A, Nachury M, Ferrante M, Kazemi-Shirazi L, Grimaud JC, de la Portilla F, Goldin E, et al. Expanded allogeneic adipose-derived mesenchymal stem cells (Cx601) for complex perianal fistulas in Crohn's disease: a phase 3 randomised, doubleblind controlled trial. Lancet. 2016; 388:1281-90.
134. Zhu M, Wang M, Yang F, Tian Y, Cai J, Yang H, Fu H, Mao F, Zhu W, Qian H, Xu W. miR-155-5p inhibition promotes the transition of bone marrow mesenchymal stem cells to gastric cancer tissue derived MSC-like cells via NF-кB p65 activation. Oncotarget. 2016; 7:16567-80. doi: 10.18632/oncotarget.7767.

135. Cho YB, Park KJ, Yoon SN, Song KH, Kim DS, Jung SH, Kim M, Jeong HY, Yu CS. Long-term results of adiposederived stem cell therapy for the treatment of Crohn's fistula. Stem Cells Transl Med. 2015; 4:532-37.

136. Dhere T, Copland I, Garcia M, Chiang KY, Chinnadurai R, Prasad M, Galipeau J, Kugathasan S. The safety of autologous and metabolically fit bone marrow mesenchymal stromal cells in medically refractory Crohn's disease - a phase 1 trial with three doses. Aliment Pharmacol Ther. 2016; 44:471-81.

137. Duijvestein M, Vos AC, Roelofs H, Wildenberg ME, Wendrich BB, Verspaget HW, Kooy-Winkelaar EM, Koning F, Zwaginga JJ, Fidder HH, Verhaar AP, Fibbe WE, van den Brink GR, Hommes DW. Autologous bone marrow-derived mesenchymal stromal cell treatment for refractory luminal Crohn's disease: results of a phase I study. Gut. 2010; 59:1662-69.

138. Barbash IM, Chouraqui P, Baron J, Feinberg MS, Etzion S, Tessone A, Miller L, Guetta E, Zipori D, Kedes LH, Kloner RA, Leor J. Systemic delivery of bone marrow-derived mesenchymal stem cells to the infarcted myocardium: feasibility, cell migration, and body distribution. Circulation. 2003; 108:863-68.

139. Freyman T, Polin G, Osman H, Crary J, Lu M, Cheng L, Palasis M, Wilensky RL. A quantitative, randomized study evaluating three methods of mesenchymal stem cell delivery following myocardial infarction. Eur Heart J. 2006; 27:1114-22.

140. Forbes GM, Sturm MJ, Leong RW, Sparrow MP, Segarajasingam D, Cummins AG, Phillips M, Herrmann RP. A phase 2 study of allogeneic mesenchymal stromal cells for luminal Crohn's disease refractory to biologic therapy. Clin Gastroenterol Hepatol. 2014; 12:64-71.

141. Liang J, Zhang H, Wang D, Feng X, Wang H, Hua B, Liu B, Sun L. Allogeneic mesenchymal stem cell transplantation in seven patients with refractory inflammatory bowel disease. Gut. 2012; 61:468-69.

142. Wu XB, Liu Y, Wang GH, Xu X, Cai Y, Wang HY, Li YQ, Meng HF, Dai F, Jin JD. Mesenchymal stem cells promote colorectal cancer progression through AMPK/mTOR-

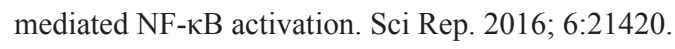

143. Hogan NM, Dwyer RM, Joyce MR, Kerin MJ. Mesenchymal stem cells in the colorectal tumor microenvironment: recent progress and implications. Int $\mathbf{J}$ Cancer. 2012; 131:1-7. 